\title{
Вплив рельєфу на формування дозового навантаження на Cryptomeria japonica, сформованого внаслідок аварії на АЕC Фукусіма-1
}

\author{
Олена Паренюк ${ }^{1,2}$, Юлія Рубан ${ }^{1}$, Наталія Нестерова ${ }^{1}$, Катерина Шаванова ${ }^{1}$ \\ ${ }^{1}$ Національний університет біоресурсів і природокористування України; Україна, \\ ${ }^{2}$ Інститут радіоактивності навколишнього середовища, Університет Фукусіма, 1, Японія \\ Адреса для листування: olena.pareniuk@gmail.com
}

\begin{abstract}
Анотація. В поданій статті розглянуто просторове розподілення дозового навантаження на фітоценози забруднених радіонуклідами внаслідок аварії на АЕС Фукусіма території. Вивчено вплив особливостей рельєфу на перерозподіл радіонуклідного забруднення у гірській місцевості. Мета роботи побудувати карту розподілу експозиційної дози не тільки навколо точок відбору проб, але й більш детально охарактеризувати навколишню територію, що може дати змогу передбачати основні патерни міграції і перерозподілу радіонуклідів у досліджуваній екосистемі. Визначити динаміку дозових навантажень на елементи фітоценозу гірських територій Японії та порівняти їх із дозами, що викликають радіобіологічні ефекти для ендеміка субальпійського поясу гір Японії Cryptomeria japonica. За допомогою Erica Tool було обраховано дози для рослин японського кедру Cryptomeria japonica, сформовані внаслідок проростання рослини на території 3 обрахованим вмістом радіонуклідів, коливались у межах від 2,65 до 121,4 мкГр за годину. В результаті проведеної роботи визначено, що особливості рельєфу мають визначальний вплив на розподіл радіонуклідного забруднення на території зони відселення, сформованої після аварії на АЕС Фукусіма-1. Поверхневий змив і горизонтальний перенос значною мірою впливають на перерозподіл забруднення, а отже, для отримання валідних результатів у довгострокових радіоекологічних дослідженнях абсолютно необхідним пунктом $\epsilon$ визначення динаміки і передбачення шляхів міграції радіонуклідів. Також можна стверджувати, що навіть при істотномі впливі рельєфу на перерозподілення радіонуклідів на досліджуваній території Наміє не буде сформовано дозу, що матиме істотний вплив на ріст і розвиток визначального для формування фітоценозу японського кедра Cryptomeria japonica.
\end{abstract}

Ключові слова: АЕС Фукусіма, радіоекологія, радіонуклідне забруднення, дозиметрія.

\section{Influence of terrain on the dose load formation on Cryptomeria japonica, formed as a result of the Fukusima-1 accident}

\author{
Olena Pareniuk $^{1,2}$, Yuliya Ruban ${ }^{1}$, Nataliya Nesterova ${ }^{1}$, Shavanova Kateryna ${ }^{1}$ \\ ${ }^{1}$ National University of Life and Environmental Sciences of Ukraine; Ukraine \\ ${ }^{2}$ Institute of Environmental Radioactivity, Fukushima University, 1, Japan \\ Correspondence: olena.pareniuk@gmail.com
}

\begin{abstract}
The presented paper considers the spatial distribution of the dose load on phytocenoses contaminated with radionuclides as a result of the accident at the Fukushima NPP area. The influence of the terrain features on the redistribution of radionuclide contamination in mountainous areas has been studied. The aim of the work was to construct a map of the absorbed dose distribution not only around the sampling points, but also to describe the surrounding area in more detail, which may allow predicting the main patterns of migration and redistribution of radionuclides in the studied ecosystem. To achieve the goal of this work, we used dosimetry and gamma-spectrometry methodologies. Maps and materials were obtained using GoogleEarth and ArcGis software packages. To determine the dynamics of dose loads on the elements of the phytocenosis of mountainous areas of Japan and compare it with doses that cause radiobiological effects for endemic subalpine
\end{abstract}


mountain belt of Japan Cryptomeria japonica. Using Erica Tool, absorbed doses for Japanese cedar plants were calculated from the content of radionuclides, ranged from 2.65 to $121.4 \mu \mathrm{Gy} / \mathrm{h}$. As a result of this work, it was determined that the features of the terrain have a decisive influence on the distribution of radionuclide contamination in the resettlement zone formed after the accident at the Fukushima-1 nuclear power plant. Surface flux and horizontal transfer significantly affect the redistribution of contamination, so to obtain valid results in long-term radioecological studies is absolutely necessary to determine the dynamics and predict the migration routes of radionuclides. It can also be argued that even with a significant effect of relief on the redistribution of radionuclides in the study area Namie will not form a dose that will have a significant impact on the growth and development of the determining factor for the formation of the Japanese cedar Cryptomeria japonica.

Key words: Fukushima NPP, radioecology, radionuclide contamination, dosimetry.

\section{ВСТУП}

Визначення дозового навантаження на забруднених радіонуклідами територіях має важливе значення для визначення життєздатності рослин, а також передбачення можливих змін у структурі фітоценозів. Базисом для будь-якого дослідження в галузі радіоекології екосистем $\epsilon$ визначення експозиційної дози та щільності забруднення на досліджуваній території. В умовах, що сформувалися на території України після аварії на ЧАЕС, зазвичай достатнім $\epsilon$ проведення зйомки невеликої території навколо точки інтересу, і згодом рівні забруднення будуть змінюватись переважно через поверхневий змив, міграцію радіонуклідів вглиб грунту, винос та розпад радіонуклідів $[1,2]$. Але саме через особливості рельєфу зони відчуження Чорнобильської АЕС вклад цих процесів мінімальний i, вимірявши щільність забруднення одного разу, можна очікувати, що через 3-6 місяців істотних змін не відбудеться. Отже, обрахунок дозового навантаження на рослини, проведений на початку року, надасть можливість передбачити радіобіологічні ефекти, що можуть проявитися протягом року. Працюючи ж у зоні відчуження (або зоні відселення, як називає iï уряд Японіiі) (Рис. 1), наша команда зіткнулася 3 абсолютно іншою ситуацією. Відбір проб проводився з проміжком у три місяці, методика i цілі дослідження, що проводилося, передбачали роботу з точковим зразком, тобто грунт відібраний 3 конкретної точки не був гомогенізований зі зразками, відібраними 3 інших точок. Тим не менш, дані щодо щільності забруднення істотно відрізняються, в деяких випадках навіть на декілька порядків (Табл. 1). Очевидно було, що основною причиною таких невідповідностей $\epsilon$ особливості рельєфу [3] - основна частина зони відселення дуже гориста, пересічена стрімкими гірськими ріками. Також для Японії характерні істотні сезонні опади - протягом кожного з сезонів тайфунів (у червні та вересні) кількість опадів може сягати декількох сотень мм за день [4]. Тому передбачення дозового навантаження на рослини, що буде сформовано протягом року, a отже, i визначення радіобіологічних ефектів, видається складним завданням.

Мета роботи - побудувати карту розподілу експозиційної дози не тільки навколо точок відбору проб, але й більш детально охарактеризувати навколишню територію, що може дати змогу передбачати основні патерни міграції i перерозподілу радіонуклідів у досліджуваній екосистемі. Визначити динаміку дозових навантажень на елементи фітоценозу гірських територій Японії та порівняти їх із дозами, що викликають радіобіологічні ефекти для ендеміка субальпійського поясу гір Японії Cryptomeria japonica. (Рис. 2). Зображення отримане як частина проекту японського уряду щодо картування радіонуклідного забруднення (MEXT).

\section{МАТЕРІАЛИ І МЕТОДИ}

Територію, де проведена гама-зйомка, було підібрано так, щоб отримати дані для різних форм рельєфу (Рис. 1): рівнина (А), на якій розташоване колишнє пасовище, крутий схил (B), пологий схил (C), водні потоки, що розташовані у невеликих каньйонах повноводна річка Такасі (R2) та гірський потік, що формується після інтенсивних опадів (R1).

Картографічні зображення і матеріали були отримані за допомогою пакетів програм GoogleEarth та ArcGis.

Точки відбору зразків були відібрані так, щоб якомога репрезентативніше представляти щільності забруднення зони відчуження, при цьому зберігаючи подібність фізико-хімічних характеритик грунту та залишаючись у межах однієї екосистеми.

Потужність експозиційної дози в польових умовах вимірювали за допомогою системи, розробленої на базі SUREC [5], що обладнана 
Науковий вісник Східноєвропейського національного університету імені Лесі Українки. Серія: Біологічні науки, 2020, 2 (390)

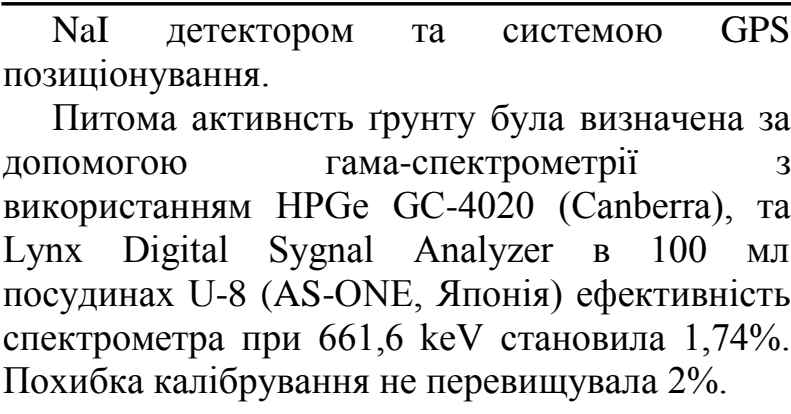

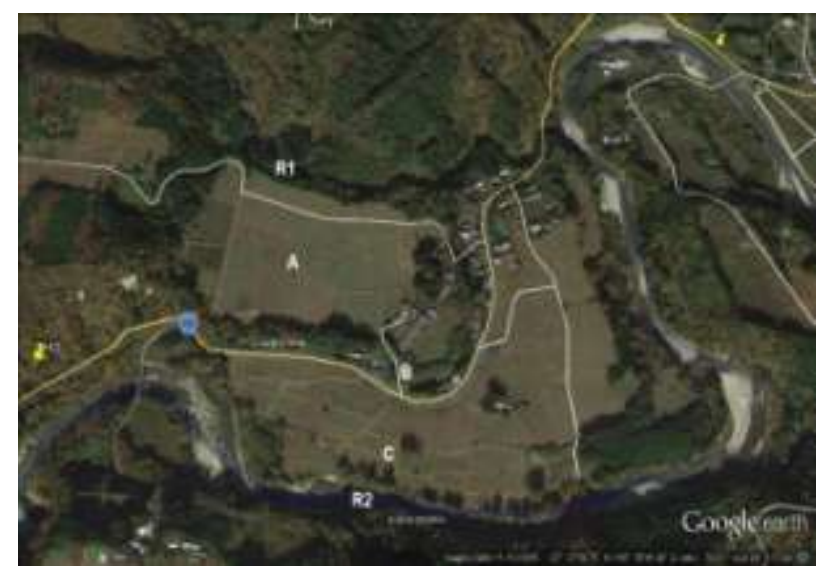

Рис. 1. Супутникова карта місиевості, де була проведена гама-зйомка (Рис. 4). Зображення отримане за допомогою GoogleEarth С. Форми рельєфу на досліджуваній території: A - пласка рівнина,

колишнс пасовище; $B-$ схил зі значним

перепадом висот; $C$-колишнє пасовище, невеликий ухил у бік ріки; Rl - гірський потік, щзо формується і наповнюється переважно під час істотних опадів, R2 - річка Такасі. $J 7$ ma

Н3 - точки відбору проб трунту.

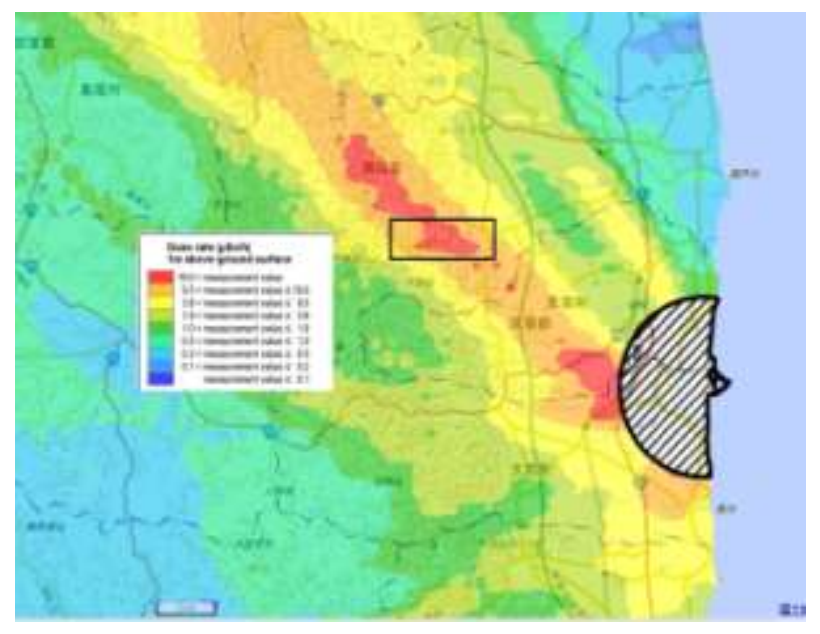

Рис.2. Радіонуклідне забруднення зони відчуження, сформованої внаслідок аварії на АЕС Фукусіма-1. Прямокутником позначена територія, де проведена гама-зйомка (Рис. 2). Зображення отримане як частина проекту японського уряду щзодо картування радіонуклідного забруднення (МЕXT).
Визначення впливу отриманого дозового навантаження на Cryptomeria japonica та оцінку радіобіологічних ефектів проводили за допомогою ERICA Tool [6].

\section{РЕЗУЛЬТАТИ І ОБГОВОРЕННЯ}

Після попереднього планування експерименту підібрали шість точок, де був запланований сезонний відбір проб грунту для генетичних досліджень. Точки буди підібрані так, щоб представляти якомога більшу варіацію питомої активності грунту. Але аналіз проб показав істотну варіабельність питомої активності (Табл. 1) та відсутність логічного пояснення таких змін. Так, наприклад, можна було 6 очікувати поступове зниження радіоактивності грунту 3 кожної точки, а особливо восени після літнього сезону тайфунів, але в точках Н3 i J7 вона підвищувалась навесні, в той час як в точці Ј5найвищою була влітку. Саме тому постала необхідність більш детальної характеристики території відбору, зокрема й ля розуміння ролі рельєфу в горизонтальному переміщенні радіонуклідного забруднення.

Таблиия 1

Зміна питомої активності зразків, відібраних у закріплених точках відбору проб протягом року

\begin{tabular}{|c|c|c|c|c|}
\hline \multirow{2}{*}{$\begin{array}{c}\text { Точка } \\
\text { від- } \\
\text { бору }\end{array}$} & \multicolumn{4}{|c|}{ Питома активність зразка, Бк/кг } \\
\hline & $\begin{array}{l}\text { липень } \\
2014\end{array}$ & $\begin{array}{c}\text { жовтень } \\
2014\end{array}$ & $\begin{array}{l}\text { лютий } \\
2015\end{array}$ & $\begin{array}{c}\text { квітень } \\
2015\end{array}$ \\
\hline $\mathrm{J} 2$ & $\begin{array}{c}1.54 \times 10^{4} \\
\pm 78\end{array}$ & $\begin{array}{c}4.03 \times 10^{4} \\
\pm 172\end{array}$ & $\begin{array}{c}4.13 \times 10^{4} \\
\pm 169\end{array}$ & $\begin{array}{c}2.9 \times 10^{3} \\
\pm 225\end{array}$ \\
\hline $\mathrm{J} 3$ & $\begin{array}{c}2.39 \times 10^{4} \\
\pm 123\end{array}$ & $\begin{array}{c}2.88 \times 10^{4} \\
\pm 127\end{array}$ & $\begin{array}{c}3.59 \times 10^{4} \\
\pm 131\end{array}$ & $\begin{array}{c}1.63 \times 10^{4} \\
\pm 185\end{array}$ \\
\hline M3 & $\begin{array}{c}8.20 \times 10^{3} \\
\pm 109\end{array}$ & $\begin{array}{c}1.01 \times 10^{4} \\
\pm 24\end{array}$ & $\begin{array}{c}2.17 \times 10^{4} \\
\pm 199\end{array}$ & $\begin{array}{c}1.86 \times 10^{4} \\
\pm 136\end{array}$ \\
\hline J5 & $\begin{array}{c}3.77 \times 10^{4} \\
\pm 177\end{array}$ & $\begin{array}{c}2.57 \times 10^{5} \\
\pm 387\end{array}$ & $\begin{array}{c}1.02 \times 10^{5} \\
\pm 267\end{array}$ & $\begin{array}{c}1.33 \times 10^{5} \\
\pm 524\end{array}$ \\
\hline H3 & $\begin{array}{c}4.11 \times 10^{5} \\
\pm 1570\end{array}$ & $\begin{array}{c}3.76 \times 10^{5} \\
\pm 662\end{array}$ & $\begin{array}{c}1.45 \times 10^{5} \\
\pm 293\end{array}$ & $\begin{array}{c}9.85 \times 10^{5} \\
\pm 4042\end{array}$ \\
\hline $\mathrm{J} 7$ & $\begin{array}{c}4.64 \times 10^{4} \\
\pm 246\end{array}$ & $\begin{array}{c}3.20 \times 10^{5} \\
\pm 116\end{array}$ & $\begin{array}{c}2.35 \times 10^{5} \\
\pm 463\end{array}$ & $\begin{array}{c}3.65 \times 10^{5} \\
\pm 790\end{array}$ \\
\hline
\end{tabular}

Для цього було вирішено провести дозиметричну зйомку території поміж двома найбільш забрудненими точками - Н3 та Ј7. Це територія залишеної ферми, де раніше проводився випас корів, і тому тут є як ділянки, вкриті трав'яною рослинністю, де за 5 років пройшла сукцесія і екосистема відновилася до альпійського різнотрав'я, так і лісові ділянки, що раніше використовували для захисту від 
Вплив рельєфу на формування дозового навантаження на Сryptomeria jаропіса, сформованого внаслідок аварії на АЕС Фукусіма-1

вітру. Також ми провели зйомку у низинах, біля водних потоків (Рис. 3).

Дані, отримані в результаті гама-зйомки, дозволили зробити припущення щодо причин флуктуації забруднення на точках відбору проб. Так, 3 відсутності накопичення радіоактивних речовин в долинах річок можна припустити високу сезонну інтенсивність водних потоків, які й виносять забруднення в океан. В той же час найбільш стабільно забрудненою виявилась найпласкіша територія, вкрита трав'яною рослинністю, а не вкритий лісом схил, як можна було б припустити виходячи 3 чорнобильських даних. Натомість колишне пасовище 3 незначним ухилом забруднено менше, ніж зазначена вище пласка територія. Саме тому можливим $\epsilon$ висновок щодо затримання радіоактивно забруднених частинок на пласких територіях та інтенсивного змиву під час тайфунів, в тому числі з винесенням мертвої біомаси 3 точок, що мають хоча б невеличкий ухил.

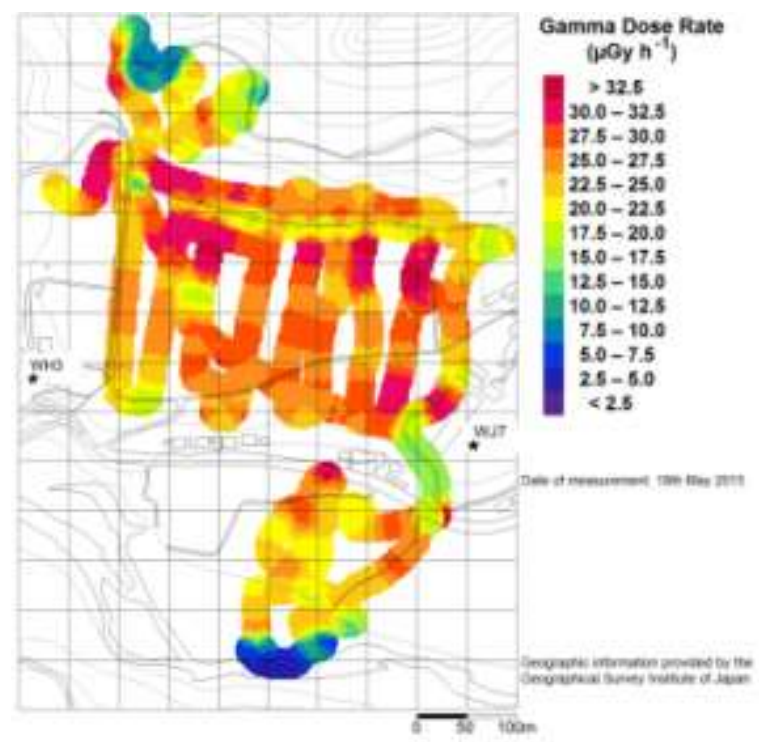

Рис. 3. Зміни дозового навантаження залежно від особливостей рельєфу

Для подальшого відстеження змін експозиційної дози на точках відбору проб були встановлені дозиметри, що дозволяють відстежувати зміни дози 3 часом. Можливо, саме дані 3 цих приладів дозволять більш детально охарактеризувати динаміку зміни забруднення на гірській території зони відселення АЕС Фукусіма-1.

За допомогою Erica Tool було обраховано дози для рослин японського кедру Cryptomeria japonica (Табл. 2), сформовані внаслідок проростання рослини на території 3 обрахованим вмістом радіонуклідів (Табл. 1).

Експозиційні дози для грунтових мікроорганізмів, сформованих на місцях відбору проб (обраховано за допомогою Erica Tool [8]).

\begin{tabular}{|c|c|c|c|c|}
\hline \multirow{2}{*}{ Код } & \multicolumn{4}{|c|}{ Потужність поглинутої дози на } \\
зразка & Сrуртотіа јаропіса, мкГр/год \\
\cline { 2 - 5 } & $\begin{array}{c}\text { липень } \\
\text { 2014 }\end{array}$ & $\begin{array}{c}\text { жовтень } \\
2014\end{array}$ & $\begin{array}{c}\text { лютий } \\
2015\end{array}$ & $\begin{array}{c}\text { квітень } \\
2015\end{array}$ \\
\hline J2 & 4,95 & 13,01 & 13,34 & 9,21 \\
\hline J3 & 7,70 & 9,30 & 11,60 & 5,27 \\
\hline M3 & 2,65 & 3,26 & 6,99 & 6,00 \\
\hline J5 & 12,16 & 82,92 & 32,96 & 43,07 \\
\hline H3 & 132,61 & 121,46 & 46,93 & 317,71 \\
\hline J7 & 14,98 & 103,16 & 75,97 & 117,69 \\
\hline
\end{tabular}

Згідно 3 опублікованими даними [7], найменші генетичні ефекти у хвойних дерев, до яких належить і японський кедр, детектовані за потужності доз у 20 мГр/день (830 мкГр/год), що істотно перевищує отримані дані.

\section{ВИСНОВКИ}

Особливості рельєфу мають визначальний вплив на розподіл радіонуклідного забруднення на території зони відселення, сформованої після аварії на АEC Фукусіма-1. Поверхневий змив і горизонтальний перенос значною мірою впливають на перерозподіл забруднення, а отже, для отримання валідних результатів у довгострокових радіоекологічних дослідженнях абсолютно необхідним пунктом $є$ визначення динаміки i передбачення шляхів міграції радіонуклідів.

Отже, можна стверджувати, що навіть при істотномі впливі рельєфу на перерозподілення радіонуклідів на досліджуваній території Наміє не буде сформовано дозу, що матиме істотний вплив на ріст і розвиток визначального для формування фітоценозу японського кедра Cryptomeria japonica.

Наукове дослідження проведено за рахунок грантової підтримки Національного фонду досліджень України (реєстраційний номер Проєкту 2020.01/0489)

\section{ЛІТЕРАТУРА}

1. Anspaugh, L. R.; Simon, S. L.; Gordeev, K. I.; et al. Movement of radionuclides in terrestrial ecosystems by physical processes. Health physics. 2002, 82 (5), pp 669-679.

2. Прохоров, В. М. Миграция радиоактивных загрязнений в почвах. Физико-химические механизмы $и$ моделирование / под ред. Р. М. Алексахина. Энергоиздат: Москва, 1981.98 с. 
3. Andoh, M.; Nakahara, Y.; Tsuda, S.; et al. Measurement of air dose rates over a wide area around the Fukushima Dai-ichi Nuclear Power Plant through a series of car-borne surveys. Journal of environmental radioactivity. 2015, 139, pp 266-280.

4. Evrard, O.; Laceby, J. P.; Lepage, H.; et al. Radiocesium transfer from hillslopes to the Pacific Ocean after the Fukushima Nuclear Power Plant accident: A review. Journal of environmental radioactivity. 2015, 148, pp 92-110.

5. Cresswell, A. J.; Sanderson, D. C. W., Harrold, M.; et al. Demonstration of lightweight gamma spectrometry systems in urban environments. Journal of environmental radioactivity. 2013, 124, pp 22-28.
6. Brown, J. E.; Alfonso, B.; Avila, R.; et al. A new version of the ERICA tool to facilitate impact assessments of radioactivity on wild plants and animals. Journal of environmental radioactivity. 2016, 153, pp 141-148.

7. Watanabe, Y. Influence of the FNPP Accident on Coniferous Trees: A Review: Low-Dose Radiation Effects on Animals and Ecosystems. Springer Singapore, 2020, 320 c.

8. Brown, J. E.; Alfonso, B.; Avila, R.; et al. The ERICA Tool. Journal of Environmental Radioactivity. 2008, 99 (9), pp 1371-1383. 